DOI: $10.2478 / \mathrm{v} 10025-007-0005-7$

JOURNAL OF WATER

AND LAND DEVELOPMENT

J. Water Land Dev. No. 10, 2006: 55-65

\title{
The function of permanent grasslands in water resources protection
}

\author{
Halina JANKOWSKA-HUFLEJT
}

Institute for Land Reclamation and Grassland Farming, Department of Grassland, Falenty, 05-090 Raszyn, Poland

\begin{abstract}
Permanent grasslands - according to the Water Framework Directive - are typical water related ecosystems so they largely affect water quality, its cycling and balance and therefore deserve protection. They are an element of landscape structure (ecosystem function or service) commonly considered a factor stabilising environmental changes.

Most threats posed to waters in Poland originate from present cropland structure with its definite predominance of arable lands over grasslands. Agriculture should therefore focus on the improvement of land use structure in order to minimise environmental hazards and to guarantee at the same time optimum economic effects. This could be achieved by turning arable lands into grasslands (where justified e.g. on light soils) or at least by maintaining present grassland area (condition in negotiations with the EU) and management that would consider environmental protection.

Increasing the contribution of grasslands to cropland structure or at least maintaining their present status quo would help to achieve compromise between the goals of farmers and environmental protection. Purposeful utilisation of ecosystem services, particularly those of grasslands, allows to maintain more intensive farming without environmental hazard. Limited should be only such activities whose intensity exceeds regenerative or buffering environmental capacity e.g. on grounds particularly subjected to water pollution or those included into Natura 2000 network.
\end{abstract}

Key words: diffuse pollution, grassland, water balance, water quality

\section{INTRODUCTION}

Restriction of agriculture-generated pollutants usually relies on conforming to the principles of environmental friendly production described by the "Code of good agricultural practices". Many natural processes like water cycling or water transport of chemical substances operate, however, in landscape or regional scale. In such a scale the restriction of water deficits or surface pollution might be effective. Permanent grasslands as typical water related and water affecting systems might be useful in that scale. Grasslands are the element of natural structure of landscapes commonly known as a factor stabilising environmental changes. 
Maintaining meadows and pastures within the framework of both agroenvironmental programmes and sustainable or ecological (extensive) farming together with maintaining small wetlands, midfield woodlots of small water bodies appears an effective tool for limiting pollution and control (RYSZKOWSKI and BAŁAZY, 1996). These are relatively simple ways of stimulation natural processes of self-purification and regeneration. Understanding and utilisation of multifunctional properties of permanent grasslands enables to compromise the targets of producer (farmer) and environmental protection.

\section{PERMANENT GRASSLANDS IN POLAND - A CHARACTERISTICS}

\section{TYPOLOGY OF PERMANENT GRASSLANDS}

Permanent grasslands in Poland comprise almost $21 \%$ of agricultural lands and $13 \%$ of the whole country area. In the year 2004 they occupied 3365.1 thousand ha, including 2390 thousand ha of meadows and 975.1 thousand ha of pastures. Nearly $90 \%$ of grasslands are the lowland grasslands, the rest comprises mountain meadows (submountain - 300-500 m a.s.l. and mountain and alpine meadows $>1000 \mathrm{~m}$ a.s.l., Fig. 1). Further on, the paper will deal with lowland grasslands only in river valleys.

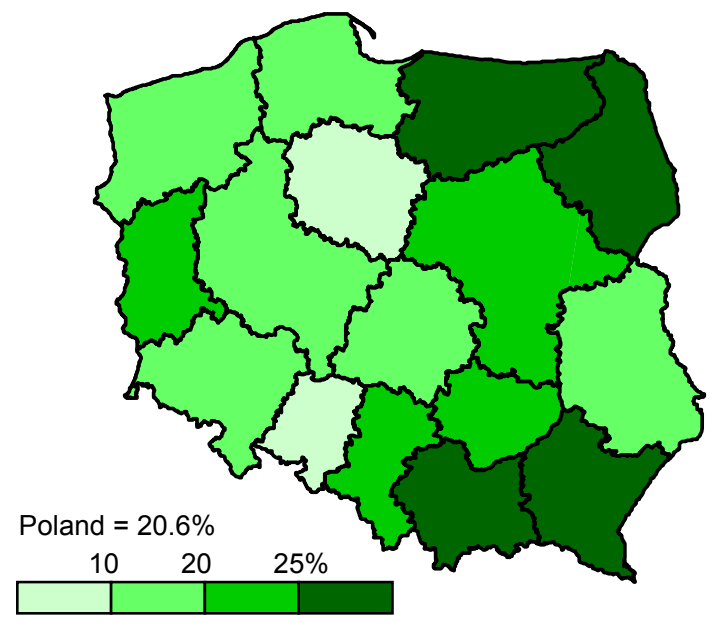

Fig. 1. Percentage share of permanent grasslands in the cropland area of particular voivodships in Poland

Due to their shallow root system, grasses take up water from the upper soil layers from a depth of 30-40 cm (with the exclusion of herbs and legumes), therefore they are associated with areas of high water tables (the so-called directly water related ecosystems). These requirements as well as the length of their vegetation period lasting usually from $1^{\text {st }}$ April till the end of October differentiate meadow 
vegetation from many other crop plants. Thus water demands of grasslands are rather high and uniform throughout the vegetation period (KOSTUCH et al., 2004).

Relation of permanent grasslands to variably wet habitats is the basis for their typologic division into four groups (GRZYB and PROŃCZUK, 1994) (Table 1).

Table 1. Groups and types of permanent grasslands according to typology and possible ways of their utilisation (GRZYB and PROŃCZUK, 1994)

\begin{tabular}{|c|c|c|c|c|}
\hline \multirow{2}{*}{$\begin{array}{l}\text { Groups of grasslands } \\
\text { Flooded meadows } \\
(20 \%)\end{array}$} & \multicolumn{4}{|c|}{$\begin{array}{c}\text { Types } \\
\text { (along increasing moisture gradient }=>\text { ) }\end{array}$} \\
\hline & $\begin{array}{l}\text { dried } \\
\square\end{array}$ & proper & with flowing water & $\begin{array}{l}\text { with stagnant } \\
\text { water }\end{array}$ \\
\hline Dry meadows (40\%) & $\begin{array}{l}\text { improverished } \\
\text { ㅇ }\end{array}$ & $\begin{array}{l}\text { proper } \\
\square\end{array}$ & $\begin{array}{l}\text { waterloggeg } \\
\square\end{array}$ & post-flooded \\
\hline $\begin{array}{l}\text { Peatland meadows } \\
(8 \%)\end{array}$ & inundated fens & bogs & proper & flooded \\
\hline $\begin{array}{l}\text { Post-peatland me- } \\
\text { adows }(32 \%)\end{array}$ & $\begin{array}{l}\text { drying moorshed } \\
\text { meadows } \square\end{array}$ & degraded & $\begin{array}{l}\text { proper moorshed } \\
\text { meadows } \square\end{array}$ & $\begin{array}{l}\text { re-glooded moor- } \\
\text { shed meadow }\end{array}$ \\
\hline
\end{tabular}

Explanations: $\square$ - intensive grazing, - grazing impossible, $\mathbf{0}$ - low-intensity grazing, $\mathbf{\square}$ - extensive periodical grazing

Flooded meadows in river valleys flooded with high or medium waters during high water tables belong to usually fertile habitats, well or excessively moistured and generally do not face water deficits. Meadow-pasture management can well be carried out there utilising valuable species and adopting management (meadow or pasture) to the level of ground water (MORACZEWSKI, 2004). They have the highest production potential.

Dry meadows, excluding wet sites, they are the habitats of poor to medium moisture since they mainly utilise precipitation waters and exceptionally flooded waters. They occupy various stands, fertile but also very poor (e.g. improverished) which are more appropriate for afforestation than for grassland management with high costs of fertilisation and irrigation.

Post peatland meadows or moorsh meadows are suitable for mown (at least twice) meadows, pastures or alternate meadow-pasture management providing necessary fertilisation, proper irrigation and nurturing. They are usually drained, therefore without irrigation and appropriate technical measures (e.g. without or with limited fertilisation with potassium and phosphorus, which are particularly low in these soils) the habitats undergo unfavourable changes in both plants and soils. Botanical composition of plants may change and during mineralization the soil may release $100-250 \mathrm{~kg} \mathrm{~N} \cdot \mathrm{ha}^{-1}$ annually. Valuable grass species guarantee the uptake of nitrogen but a lack of dense plant cover may result in nitrogen transport to ground 
and surface waters and partly to the atmosphere. The peat is pulverised and eventually peat soils loose their physical and water properties for ever. The soils may also fissure to several dozen centimetres deep which leads to peat mineralization with all its consequences [KOSTUCH et al., 2004].

Marsh meadows or peatland meadow are typical potential meadows which need expensive reclamation investments because of their excessive moisture during the whole season. They are mostly overgrown by sedge communities with mosses in the undergrowth layer. Not used in agriculture they are biologically valuable habitats. After drainage and management they could become proper grasslands included in the post-bog group of meadows.

\section{NON-PRODUCTIVE FUNCTIONS OF PERMANENT GRASSLANDS AND TARGETS OF THE WATER FRAMEWORK DIRECTIVE}

\section{REGULATION OF WATER CONDITIONS}

Grounds situated low and covered by permanent grassland vegetation play a great role in water balance. Vegetation creates natural retention and so increases available water resources. Economic and ecological role of water is not determined by its absolute amount in a given area but by the time during which it plays its various functions, in other words - the time of its persistence in the landscape. The latter in turn depends on the degree of vegetation cover and on the time of the flow of precipitation water to rivers (KĘDZIORA, 2005). Liquidation (degradation) of vegetation decreases retention capacity of catchments and accelerates soil erosion.

Permanent grasslands occupy $13 \%$ of the country area in Poland and may use c. 10-15 billion $\mathrm{m}^{3}$ of water annually (at an average dry weight yield of $4.6 \mathrm{t} \cdot \mathrm{ha}^{-1}$ in 2004). Riparian meadows comprising $20 \%$ of grasslands are most important in retaining over 5 billion $\mathrm{m}^{3}$ of water (PROŃCZUK, 1979).

Together with forests, permanent grasslands play a significant role in improving air humidity. Situated mainly in river valleys, in terrain depressions and in mountain valleys (higher soil moisture) grasslands use much water - transpiration coefficient ranges from 600 to 15001 of water per $1 \mathrm{~kg}$ of dry weight. However, only small part of the water is used for biomass increment and the atmosphere receives large amounts of water in the form of water vapour (c. 5 million litres per ha of meadows during the vegetative season (MISZTAL, 1996).

After night cooling water in a form of vapour, mist, dew or even precipitation partly returns to the area from where it was evaporated or to adjoining areas thus improving their water relations (NICZYPORUK, 2000).

Equally important is the role of permanent grasslands as the so-called biological flood control measure. In concordance with the Water Framework Directive philosophy, apart from purely technical measures (embankments and retention res- 
ervoirs), terrain depressions densely overgrown with permanent grasslands (flooded polders) are used in flood control. This enables to effectively cut off the flood wave and periodically retain water (RYSZKOWSKI et al., 2003). This way grasslands operate as the areas of flood relief (or the so-called dry reservoirs) for controlled water flow during extremely high waters. Spring inundation that prolongs for even 30 days does not make any harm to plants; conversely, it stimulates plant growth and maintains greater number of species. High water that prolongs over three days in the summer may result in losses of less resistant plants.

Meadow and pasture use of the river valley allows to mitigate the requirements of flood control and, in extreme cases, to restrict the range of technical antiflood protection. Periodical inundation of extensively used meadows and pastures might be relatively simple and free from economic losses (MIODUSZEWSKI, 2004).

THE EFFECT OF PERMANENT GRASSLANDS ON WATER QUALITY AND THEIR ROLE IN COUNTERACTING SOIL EROSION

Permeation of mineral nutrients and toxic substances from soil to ground waters takes place as a result of infiltration, surface runoff and water and aeolian erosion. The latter two are the processes that pose serious threat to soil fertility. Water erosion from the area of Poland to the Baltic Sea is estimated at 5 million $t$ of soil per year i.e. the loss of 60 thousand tons of $18 \%$ superphosphate, 150 thousand tons of $20 \%$ potassium salt, 70 thousand t of $25 \%$ nitrochalk and 80 thousand t of burnt lime (ZIEMNICKI, JÓZEFACIUK, 1965 cited after KUREK Z., KUREK S., 1999). On the other hand, mean annual runoff from loess drainage basin covered in $90 \%$ by arable grounds amounted 32 thousand $\mathrm{kg} \cdot \mathrm{km}^{-2}\left(320 \mathrm{~kg} \cdot \mathrm{ha}^{-1}\right)$ including 1630 $\mathrm{kg} \cdot \mathrm{km}^{-2}$ of dissolved salts (MAZUR and PAŁYS, 2005).

Thus erosion unfavourably affects soil fertility and crops but also is it the main reason of the surface water pollution. The extent of this process is mainly determined by the agricultural type of land use.

Grasslands positively mitigate erosion. As long as the total plant cover is maintained (plants are not destroyed by heavy machines or excessive grazing) the erosion is negligible.

Pollutants left on the surface of a grassland, lawn or meadow quickly become decomposed due to an intensive biological activity of soil microorganisms associated with grassland ecosystems and to saprophytic activity of small mesofauna living there. Thanks to this, grasslands are best fit from among all agricultural crops to play a role of biological filter. Dense root system and well developed bacterial flora are important features for this role. The first sequesters much of nutrients and retains suspensions; the second performs rapid mineralisation of organic matter and takes up nutrients as well (NAZARUK and PIEKUT, 1999). 
RYSZKOWSKI et al. (2003) reported that meadows (at least 8-10 m wide biogeochemical barrier) removed $64-97 \%$ (90\% on average) of nitrates from water percolating through their root systems (Table 2). Excess of nitrates probably accumulates in a form of organic nitrogen in the root zone (root uptake and soil sorption) and therefore it is not washed out from soil. Therefore, grasslands as well as midfield shelterbelts and small water bodies are the barriers limiting migration of various chemicals or materials from croplands to surface and ground waters.

Table 2. The effect of plant cover on water chemistry on the Samica River - 1987 (FALKOwSKI et al., 1996)

\begin{tabular}{|c|c|c|c|c|}
\hline \multirow{2}{*}{ Season } & \multirow{2}{*}{$\begin{array}{l}\text { Water flowing } \\
\text { by complex }\end{array}$} & \multicolumn{3}{|c|}{ Content, $\mathrm{mg} \cdot \mathrm{dm}^{-3}$} \\
\hline & & \multicolumn{2}{|c|}{$\mathrm{N}-\mathrm{NO}_{3}$} & $\mathrm{P}$ \\
\hline \multirow[t]{2}{*}{ Spring (25.04) } & meadow & 11,5 & $5,0 *$ & 0.000 \\
\hline & agro & 28,0 & $13,0^{*}$ & 0,008 \\
\hline \multirow[t]{2}{*}{ Summer (15.07) } & meadow & 2,8 & - & 0,139 \\
\hline & agro & 28,4 & - & 0,376 \\
\hline \multirow[t]{2}{*}{ Autumn (08.10) } & meadow & 3,0 & - & 0,038 \\
\hline & agro & 18,6 & - & 0,071 \\
\hline
\end{tabular}

Explanations: * ac. RYSZKOWSKI et al. (2003), ,-“ ' no date.

It was demonstrated that nitrogen outflow from arable lands (e.g. black fallow), even non-fertilised, was $69.2 \mathrm{~kg} \mathrm{~N} \cdot \mathrm{ha}^{-1}$ i.e. 10.3 times more than permanent grassland fertilised with $\mathrm{N}$ at a rate of $240 \mathrm{~kg} / \mathrm{ha}$ (KUREK Z., KUREK S., 1999). KOPEĆ (1999) showed nitrogen losses ranging from $5.0-7.6 \mathrm{~kg} \mathrm{~N} \cdot \mathrm{ha}^{-1}$ of grassland fertilised at a rate of up to $240 \mathrm{~kg} / \mathrm{ha}$. The dose of $360 \mathrm{~kg} \cdot \mathrm{ha}^{-1}$ increased losses to $16.4 \mathrm{~kg} \mathrm{~N} \cdot \mathrm{ha}^{-1}$, it is to $3 \%$ of applied dose.

Positive effects for water quality may be obtained by organization of grassland management since changes in plant communities and floristic types of meadows are followed (though delayed in time as e.g. peat mineralisation) by habitat changes. Different height and frequency of mowing through affecting floristic composition may also alter chemical composition of plant biomass, the ratio of generative to vegetative shoots and the length of roots penetrating soil-water habitat. Root length is associated with enhanced infiltration of rainfall (with nutrients) down the soil profile and transfer of nutrients to the upper subsurface soil layers which prevents them from turning barren.

Studies carried out on plots sensitive to pollution, where water runoff was small, demonstrated that alternate utilisation (mowing and grazing one after another) is better than one-sided use (e.g. exclusive grazing) because of smaller nitrogen losses due to leaching. An example of nitrogen losses and nitrate concentrations in relation to grassland use at the same nitrogen fertilisation is shown in Table 3. 
Table 3. Nitrogen losses and nitrate concentrations in ground water in relation to the use of grassland fertilised with $250 \mathrm{~kg} \mathrm{~N} \cdot \mathrm{ha}^{-1}$

\begin{tabular}{l|c|c}
\hline Utilisation & $\begin{array}{c}\text { Nitrate concentration } \\
\mathrm{mg} \cdot \mathrm{dm}^{-3}\end{array}$ & $\begin{array}{c}\text { Annual N losses } \\
\mathrm{kg} \cdot \mathrm{ha}^{-1}\end{array}$ \\
\hline Mowing + grazing & 45 & 9.5 \\
Grazing & 130 & 25.0 \\
\hline
\end{tabular}

Acc. to DeCAU and SALETTE (1994).

As can be seen, self-purification of water depends on the structure of ecosystems that form a given area. Increasing their resistance to degradation is accomplished by stimulating natural processes of purification and neutralisation of pollutants and by increased effectiveness of self-purification, water retention and regeneration of humus resources (RYSZKOWSKI et al. 2003). In meadows and pastures overgrown by perennial grassland vegetation humus is accumulated as a result of the turfing process. Grasslands are the largest resource of natural humus.

Organic matter increases soil retentiveness since it retains more water than mineral matter. Moreover, organic matter improves soil structure and increases the number of mean-sized pores decisive for the availability of water to plants. An increase of organic matter content in soils by $1 \%$ means the increase of water retention in the upper arable $30 \mathrm{~cm}$ of soil by $10 \mathrm{~mm}$ i.e. by $100 \mathrm{~m}^{3}$ per ha at every larger rainfall. At the same time hygrothermal conditions in soil are improved which favours the activity of microorganisms and soil fauna (KĘDZIORA, 2005).

The legumes have the significant importance for water quality and soil fertility, and also for the amount and quality of yield from permanent grasslands and decrease of energy consumption for production of mineral $\mathrm{N}$ fertilisers

The plants fix globally over 170 million tons of available nitrogen while its production is 80 million tons (10 million in the EU in the year 2000). That's why legumes are so important in grassland sward. When their contribution to sward amounts $20-30 \%$, fertilisation with $60 \mathrm{~kg} \mathrm{~N} \cdot \mathrm{ha}^{-1}$ is sufficient and $30-50 \%$ share of legumes secures appropriate sward density and plant cover in grassland. This way they diminish nitrogen losses through leaching and volatilisation. Leaching in that case may be even four times smaller than that from typical permanent grasslands intensively fertilised with nitrogen. VERT's et al. [1995] shows that $\mathrm{N}$ nitrate leaching from rye-grass sward was $68.3 \mathrm{~kg}$ from ha and only $1.6 \mathrm{~kg}$ from ha from legume-grass sward.

Other non-productive aspects of the presence of legumes in permanent grasslands include the enhancement of biological activity, fertility, soil improvement and protection against erosion. Consequently, soil structure is regenerated while porosity and water capacity increases (long root system). Legumes together with grasses exert the greatest structure forming impact on soil from among other plants. Apart from water infiltration they affect faster production of soil clods thanks to 
root excretions that play a role of binding agent (KOSTUCH and GA_SIOREK, 1999). Free spaces among clods allow for collecting water and air. Such soil has greater water retention, is better aerated and thus creates more favourable conditions for the development of microorganisms and for biochemical processes.

\section{SUMMARY}

Permanent grasslands - according to the Water Framework Directive - are typical water related ecosystems so they largely affect water quality, its cycling and balance and therefore deserve protection. They are an element of landscape structure (ecosystem function or service) commonly considered to be a factor stabilising environmental changes.

Most threats posed to waters in Poland originate from present cropland structure with its definite predominance of arable lands over grasslands. Agriculture should therefore focus on the improvement of land use structure in order to minimise environmental hazards and to guarantee at the same time optimum economic effects. This could be achieved by turning arable lands into grasslands (where justified e.g. on light soils) or at least by maintaining present grassland area (condition in negotiations with the EU) and management that would consider environmental protection among others:

- adjustment of intensity of agricultural use to natural conditions,

- achieve equilibration of nutrient cycling in a farm,

- using fertilisation mainly with farm fertilisers (manure).

Increasing the contribution of grasslands to cropland structure or at least maintaining their present status quo would help to achieve compromise between the goals of farmers and environmental protection. Purposeful utilisation of ecosystem services, particularly those of grasslands, allows to maintain more intensive farming without environmental hazard. Only such activities should be limited whose intensity exceeds regenerative or buffering environmental capacity e.g. on grounds particularly subjected to water pollution or those included into Natura 2000 network.

Countries of modern, highly productive agriculture prefer production on permanent grasslands. They cover e.g. in Austria - nearly 57\%, in Belgium and The Netherlands $-45 \%$, in France $-39 \%$ and in Switzerland $-80 \%$ of croplands while in Poland they occupy not more than $20 \%$ (13\% of the whole country area).

Man should understand that environmental hazards appear as a result of ignorance of civilization process and not as its consequence. Gaps in understanding the possibilities of increasing landscape resistance to degradation through modelling its spatial structure, in our case through expanding or maintaining present areas of grasslands, make the local development plans are based on bans and restrictions 
leading to extensification of economic activity or even to its abatement or suspension contrary to the intentions and aims of the Water Framework Directive.

\section{REFERENCES}

1. Decau M.L., Salette J. 1994. Reducing nitrate leaching by manipulating the cutting/grazing and N fertilisation level regimes. Proc. $15^{\text {th }}$ Gen. Meet. EGF Wageningen: 233-237.

2. DRUPKA S., 2004. Plonowanie użytków zielonych - warunki wodne. Możliwości poprawienia gospodarowania wodą na użytkach zielonych przez zastosowanie samoregulujących zastawek melioracyjnych. W: Perspektywy gospodarowania na trwałych użytkach zielonych w ramach „Wspólnej polityki rolnej UE”. (Yielding of grasslands - water conditions. Possibilities of improving water management on grasslands through the application of self-regulating reclamation sluices. In: The perspectives of management on permanent grasslands within the "Common agricultural policy of the EU"). Pr. zbior. Red. H. Jankowska-Huflejt. Mater. Semin. 48. Falenty, Wydaw. IMUZ: 7790.

3. Falkowski M., KukUŁKa I., KozŁowski S., 1996. Łąka jako bariera ekologiczna migracji składników mineralnych do wód. (Meadow as an ecological barrier of mineral components migration to waters). Rocz. AR Pozn. 284 Rol. 47: 97-103.

4. GRZYB S., ProŃCZUK J., 1994. Podział i waloryzacja siedlisk łąkowych oraz ocena ich potencjału produkcyjnego. W: Kierunki rozwoju łąkarstwa na tle aktualnego poziomu wiedzy w najważniejszych jego działach. (Division and evaluation of meadow habitats and the assessment of their productive potential. In: Development of the grassland science in view of the present knowledge in its most important branches). Mater. Ogólnopol. Konf. Łąk. Warszawa 27-28 września 1994, Warszawa, Wydaw. SGGW: 51-63.

5. KęDZIORA A., 2005. Przyrodnicze podstawy gospodarowania wodą w Polsce. W: Ochrona środowiska w gospodarce przestrzennej. (Biological basis of water management in Poland. In: Environmental protection in spatial planning). Poznań, ZBŚRiL PAN: 74-113.

6. MiszTAL A., 1996. Kształtowanie się ewapotranspiracji i infiltracji z łąki górskiej w zależności od występowania wód gruntowych. (Evapotranspiration and infiltration from a mountain meadow in relation to the occurrence of ground waters). Zesz. Probl. Post. Nauk Rol. 442: 323-332.

7. KOPEĆ S., 1999. Rola użytków zielonych w ochronie wód. W: Rola użytków zielonych i zadrzewień $\mathrm{w}$ ochronie środowiska rolniczego. (The role of grasslands in water protection. In: The role of grasslands and woodlots in the protection of agricultural environment). Międz. konf. nauk.-tech. Kraków-Jaworki 21-22.11.1999: 141-151.

8. Kostuch R., GĄSIOREK S., 1999. Roślinność jako wielofunkcyjna dominanta oddziaływań ekologicznych na środowisko przyrodnicze. W: Szata roślinna jako wielofunkcyjna dominanta ilościowo-jakościowych zasobów wodnych w górach. (Vegetation as a multifunctional dominant of ecological influence on the environment. In: Vegetation cover as a multifunctional dominant of the quantitative and qualitative water resources in the mountains). Konf. Jaworki 8-9 października 1998. Falenty, Wydaw. IMUZ: 11-20.

9. Kostuch R., NAZAruK M., GutKowsKa A., 2004. Reakcja zbiorowisk łąkowych na długotrwałą suszę. (Reaction of meadow communities on a long-standing drought). Wiad. Melior. nr 2: 79-83.

10. KUREK Z., KUREK S., 1999. Zagrożenie środowiska przyrodniczego przez rolnictwo. W: Szata roślinna jako wielofunkcyjna dominanta ilościowo-jakościowych zasobów wodnych w górach. (Agricultural hazard to the environment. In: Vegetation cover as a multifunctional dominant of the quantitative and qualitative water resources in the mountains). Mater. Semin. 42. Falenty, Wydaw. IMUZ: 21-35. 
11. MAZUR A., PAŁys S., 2005. Odpływ wody, gleby i soli z rolniczej zlewni lessowej w latach 1988-2004. (The outflow of water, soil and salt from loess agricultural catchment in the years 19882004). Wiad. Melior. 1: 26-28.

12. MiodusZEWSKI W., 2004. Ochrona przed powodzią a walory przyrodnicze dolin rzecznych. (Flood control and the natural values of river valleys). Wiad. Melior. 1: 33-37.

13. MoraCZEWSKI R., 2004. Techniki i technologie produkcji pasz na trwałych użytkach zielonych sprzyjające ochronie środowiska. W: Perspektywy gospodarowania na trwałych użytkach zielonych w ramach „Wspólnej polityki rolnej UE”. (Environmental friendly techniques and technologies of fodder production on permanent grasslands. In: The perspectives of management on permanent grasslands within the "Common agricultural policy of the EU"). Pr. zbior. Red. H. JankowskaHuflejt. Mater. Semin. 48. Falenty, Wydaw. IMUZ: 51-62.

14. NAZARUK M., PieKuT K., 1999. Oczyszczanie ścieków na użytkach zielonych. W: Rola użytków zielonych i zadrzewień w ochronie środowiska rolniczego. (Wastewater treatment on grasslands. In: The role of grasslands and woodlots in the protection of agricultural environment). Międz. konf. nauk.-techn. Kraków-Jaworki 21-22.11.1999: 231-246.

15. NiCZYPORUK A., 2000. Ekosystemy trawiaste w kształtowaniu i ochronie środowiska. (Grassland ecosystems in environmental management and protection). Białystok, Wydaw. PB.

16. ProŃCZUK J., 1979. Użytki zielone w świetle nowoczesnych pojęć ekologicznych i gospodarczych. (Grasslands in view of the modern ecological and economic terms). Wiad. Ekol. 16.

17. RYSZKOWSKI L., BAŁAZY S., 1996. Conservation of natural heritage and nature protection in rural areas of Poland. In: Landscape diversity: a chance for the rural community to achieve a sustainable future. Ed. L. Ryszkowski, G. Pearson, S. Bałazy. Res. Centre Agricult. Forest Env. Poznań: 147-159 .

18. RyszKowski L., BAŁAZY S., KęDziora A., 2003. Kształtowanie i ochrona zasobów wodnych na obszarach wiejskich. (Management and protection of water resources in rural areas). Poznań, ZBŚRiL PAN: 70.

19. RYSZKOWSKI L., 2005. Znaczenie funkcjonalnej analizy krajobrazu dla zagospodarowania przestrzennego. W: Ochrona środowiska w gospodarce przestrzennej. (The importance of functional landscape analysis for spatial planning. In: Environmental protection in spatial planning). Poznań, ZBŚRiL PAN: 49-72.

20. VerT's F., Simon J.C., CorRe L.Le, 1994. Nitrate leaching under pasture: study of the soil-plant system in a lysimeter experiment. Proc. $15^{\text {th }}$ Gen. Meet. EGF Wageningen: 466-470.

\section{STRESZCZENIE}

\section{Funkcje trwałych użytków zielonych w ochronie zasobów wodnych}

Słowa kluczowe: bilans wodny, jakość wody, ograniczanie zanieczyszczeń, użytki zielone

Trwałe użytki zielone (TUZ) - zgodnie z treścią RDW - są typowymi ekosystemami od wód zależnymi czyli mającymi duży wpływ przede wszystkim na ich jakość, ale także na przedłużanie ich obiegu i poprawę bilansu wodnego, i dlatego podlegającym ochronie. Są elementem struktury przyrodniczej krajobrazu (funkcja lub usługa ekosystemu) powszechnie uważanym za czynnik stabilizujący procesy zmian środowiska naturalnego. 
Większość zagrożeń wód w Polsce wiąże się z aktualną strukturą użytków rolnych, charakteryzującą się zdecydowana przewagą gruntów ornych nad użytkami zielonymi. Działalność rolnicza powinna więc iść w kierunku poprawy struktury rolniczego użytkowania ziemi tak, aby w danych warunkach środowiskowych stanowiło ono jak najmniejsze zagrożenie dla środowiska, gwarantując jednocześnie optymalne efekty ekonomiczne. Działania te to zamiana gruntów ornych na trwałe użytki zielone (tam gdzie jest to uzasadnione, np. gleby b. lekkie) lub przynajmniej utrzymanie dotychczasowej ich powierzchni (warunek w zapisach negocjacyjnych z Unia) oraz gospodarowanie uwzględniające ochronę środowiska.

Zwiększenie udziału TUZ w strukturze użytków rolnych, lub przynajmniej utrzymanie ich dotychczasowej powierzchni, sprzyja osiagnięciu kompromisu celów rolnika producenta i ochrony środowiska. Świadome bowiem wykorzystanie usług ekosystemów, w tym szczególnie użytków zielonych, pozwala na utrzymanie intensywniejszych form gospodarowania bez zagrożeń środowiska. Ograniczane powinny być tylko te działania, których intensywność istotnie przekracza zdolności regeneracyjne i buforowe środowiska, np. na terenach szczególnie narażonych na zanieczyszczenia wód, np. zaliczane do sieci Natura 2000.

Reviewers:

Prof. Waldemar Mioduszewski

Prof. Czestaw Przybyta 